\author{
Abstracta Iranica \\ Abstracta Iranica Revue bibliographique pour le domaine irano-aryen \\ Volume 32-33 | 2013 \\ Comptes rendus des publications de 2009-2010
}

\title{
Oded Lipschits et al. The 2006 and 2007 Excavation Seasons at Ramat Rahel: Peliminary Report
}

\section{Astrid Nunn}

\section{(2) OpenEdition}

1 Journals

\section{Édition électronique}

URL : http://journals.openedition.org/abstractairanica/40371

DOI : 10.4000/abstractairanica.40371

ISSN : 1961-960X

Éditeur :

CNRS (UMR 7528 Mondes iraniens et indiens), Éditions de l'IFRI

\section{Édition imprimée}

Date de publication : 1 décembre 2013

ISSN : 0240-8910

\section{Référence électronique}

Astrid Nunn, "Oded Lipschits et al. The 2006 and 2007 Excavation Seasons at Ramat Rahel: Peliminary Report », Abstracta Iranica [En ligne], Volume 32-33 | 2013, document 97, mis en ligne le 01 juillet 2016, consulté le 03 octobre 2020. URL : http://journals.openedition.org/abstractairanica/40371 ; DOI : https://doi.org/10.4000/abstractairanica.40371

Ce document a été généré automatiquement le 3 octobre 2020.

Tous droits réservés 


\title{
Oded Lipschits et al. The 2006 and 2007 Excavation Seasons at Ramat Rahel: Peliminary Report
}

\author{
Astrid Nunn
}

\section{RÉFÉRENCE}

Oded Lipschits et al. « The 2006 and 2007 Excavation Seasons at Ramat Rahel: Peliminary Report ». IEJ 59/1, p. 1-20.

1 Sous les couches islamiques et byzantines du site de Ramat Rahel, à mi-chemin entre Jérusalem et Bethléem, se situent un mur de défense de l'âge du Fer (Area D2) ainsi que des canalisations et des bassins (Area C1) qui devaient alimenter un jardin et qui peutêtre subsistaient encore à l'époque achéménide.

\section{AUTEURS}

\section{ASTRID NUNN}

Université de Munich 